\title{
Iron(III) complexes of certain tetradentate phenolate ligands as functional models for catechol dioxygenases
}

\author{
MALLAYAN PALANIANDAVAR,* MARAPPAN VELUSAMY and \\ RAMASAMY MAYILMURUGAN \\ School of Chemistry, Bharathidasan University, Tiruchirapalli 620024 \\ e-mail: palani51@sify.com
}

\begin{abstract}
Catechol 1,2-dioxygenase (CTD) and protocatechuate 3,4-dioxygenase (PCD) are bacterial non-heme iron enzymes, which catalyse the oxidative cleavage of catechols to cis, cis-muconic acids with the incorporation of molecular oxygen via a mechanism involving a high-spin ferric centre. The iron(III) complexes of tripodal phenolate ligands containing $\mathrm{N}_{3} \mathrm{O}$ and $\mathrm{N}_{2} \mathrm{O}_{2}$ donor sets represent the metal binding region of the iron proteins. In our laboratory iron(III) complexes of mono- and bisphenolate ligands have been studied successfully as structural and functional models for the intradiol-cleaving catechol dioxygenase enzymes. The single crystal X-ray crystal structures of four of the complexes have been determined. One of the bis-phenolato complexes contains a $\mathrm{FeN}_{2} \mathrm{O}_{2} \mathrm{Cl}$ chromophore with a novel trigonal bipyramidal coordination geometry. The Fe-O-C bond angle of $136 \cdot 1^{\circ}$ observed for one of the iron(III) complex of a monophenolate ligand is very similar to that in the enzymes. The importance of the nearby sterically demanding coordinated $-\mathrm{NMe}_{2}$ group has been established and implies similar stereochemical constraints from the other ligated amino acid moieties in the 3,4-PCD enzymes, the enzyme activity of which is traced to the difference in the equatorial and axial Fe-O(tyrosinate) bonds ( $\mathrm{Fe}-\mathrm{O}-\mathrm{C}, 133,148^{\circ}$ ). The nature of heterocyclic rings of the ligands and the methyl substituents on them regulate the electronic spectral features, $\mathrm{Fe}^{\mathrm{III}} / \mathrm{Fe}^{\mathrm{II}}$ redox potentials and catechol cleavage activity of the complexes. Upon interacting with catecholate anions, two catecholate to iron(III) charge transfer bands appear and the low energy band is similar to that of catechol dioxygenase-substrate complex. Four of the complexes catalyze the oxidative cleavage of $\mathrm{H}_{2} \mathrm{DBC}$ by molecular oxygen to yield intradiol cleavage products. Remarkably, the more basic $\mathrm{N}$-methylimidazole ring in one of the complexes facilitates the rate-determining productreleasing phase of the catalytic reaction. The present study provides support to the novel substrate activation mechanism proposed for the intradiol-cleavage enzymes.
\end{abstract}

Keywords. 1,2-CTD enzymes; functional and structural models; Fe(III) complexes; phenolate ligands; intradiol cleavage.

\section{Introduction}

Mononuclear non-heme iron centres are frequently present in a variety of protein systems which perform important biological functions involving dioxygen. ${ }^{1-4}$ The oxidative cleavage of catechol and other dihydroxy aromatics is a key step in the biodegradation by soil bacteria of naturally occurring aromatic molecules and many aromatic environmental pollutants. ${ }^{6}$ The mononuclear non-heme iron proteins that catalyse the oxidative cleavage ${ }^{5}$ of catechol or its derivatives with the incorporation of molecular oxygen are exemplified by catechol dioxygenases. If two of the hydroxyl substituents in the catechol substrate are in ortho positions then ring cleavage can occur either between the two groups (intradiol) or between

*For correspondence one hydroxyl group and an adjacent carbon atom (extradiol). ${ }^{7}$ The X-ray crystal structure of the intradiol cleaving protocatechuate 3,4-dioxygenase (PCD) from Pseudomonas putida reveals a trigonal bipyramidal iron(III) site with four endogenous protein ligands (Tyr408, Tyr447, His460 and His462) and a solvent-derived ligand. ${ }^{8} \mathrm{~A}$ very similar active site has been found ${ }^{9}$ recently for another member of the intradiol dioxygenase family, namely, catechol 1,2-dioxygenase (CTD). The spectroscopic properties of the $\mathrm{Fe}(\mathrm{III})$ centre are alter by substrate binding to active site.

As the interaction of iron(III) with phenolate moieties of tyrosine residues plays an important role in the enzyme function and in stabilizing the active site geometries of CTD and PCD enzymes, iron(III) complexes of phenolate ligands have attracted much interest as models to mimic the enzyme active sites 
and function. From the point of view of models for dioxygenases, fundamental work by Funabiki et al on the catalytic intra- and extradiol oxygenations of 3,5-di-tert-butylcatechol $\left(\mathrm{H}_{2} \mathrm{DBC}\right)$ by a py/bipy/ $/ \mathrm{FeCl}_{3}$ complex appeared. ${ }^{10-12}$ In early studies Que and coworkers $^{13-15}$ synthesised a series of nitrogen, carboxylate and phenolate containing iron(III) complexes, the catalytic properties of which have been explored. Indeed they found a clear relationship between the reactivity of the adducts and Lewis acidity of the iron(III) centres as modulated by the tripodal ligand, which plays an important role in dictating the catecholate-to-iron(III) charge transfer absorptions occurring in the visible region. The tripodal ligand complexes reported by Nishida ${ }^{16}$ and Que ${ }^{13,15}$ to effect oxidative cleavage contain a coordinated phenolate group, in addition to pyridyl moieties.

Model compounds synthesised ${ }^{17-19}$ previously by us are derived from both mono- and bis(phenolate) tripodal ligands with pyridine/benzimidazole pendants and were used to cleave the substrate analogue $\mathrm{H}_{2}$ DBC. These ligands provide a reasonable analogue to histidine and tyrosinate coordination in CTD enzyme via the bzim and phenolate moieties. The study of iron(III) complexes of certain simple tridentate ligands with both phenolate and imidazole functionalities also provided the information pertinent to understanding of structure vs spectra correlations and the function and reactivity of the active site. A linear correlation between the $\mathrm{Fe}^{\mathrm{III}} / \mathrm{Fe}^{\mathrm{II}}$ redox potential and the CT band energy of complexes was obtained. The catalytic activity of the complexes has been correlated with the $\mathrm{Fe}^{\mathrm{III}} / \mathrm{Fe}^{\mathrm{II}}$ as well DBSQ/ DBC [DBSQ = 3,5-di-tert-butyl-1,2-benzoquinone] redox couples. Also the dioxygenase activity was illustrated on the basis of the Lewis acidity of the complex-DBC ${ }^{2-}$ adducts, derived from the magnitude of the $\mathrm{CAT}^{2-} / \mathrm{DBC}^{2-} \rightarrow \mathrm{Fe}(\mathrm{III}) \mathrm{CT}$ band energy and the $E_{1 / 2}$ of the DBSQ/DBC ${ }^{2-}$ couple and steric hindrance to substrate binding and by assuming that the product release is the rate-determining phase of the reaction.

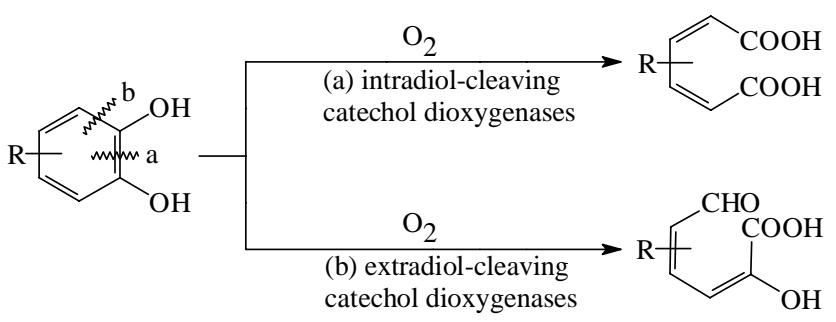

Scheme 1. Cleavage modes of catechol.
In the present review we summarise our very recent work $^{18,19}$ on synthetic analogues for intradiolcleaving catechol dioxygenases. We have isolated mononuclear iron(III) complexes of sterically hindered tetradentate mono- and bisphenolate ligands, which are expected to closely mimic the enzyme active site structure and function. The steric and electronic influence of the ligand nitrogen donor set on the spectral and redox behaviour and the dioxygenase activity of the complexes has been probed. The X-ray crystal structures of some of the complexes have been determined to demonstrate the availability of two cis coordination sites for adduct formation by substrate molecules. We have used $\mathrm{H}_{2} \mathrm{DBC}$ as the model substrate and the advantages are the relatively high stability of the main cleavage product and the fast reaction of the catecholate complexes with dioxygen.

\section{Synthesis of mono- and bis-phenolate ligands and isolation of their iron(III) complexes}

The monophenolate ligands 2-bis(pyrid-2-ylmethyl) aminomethyl-4-nitrophenol [H(L1)], N,N-dimethyl$\mathrm{N}^{\prime}$-(pyrid-2-yl-methyl)-N'-(2-hydroxy-4-nitrobenzyl) ethylene-diamine $[\mathrm{H}(\mathrm{L} 2)], \quad \mathrm{N}, \mathrm{N}$-dimethyl-N'-(6methylpyrid-2-ylmethyl)- $\mathrm{N}^{\prime}$-(2-hydroxy-4-nitrobenzyl)ethylenediamine $\mathrm{H}(\mathrm{L} 3)]$ and $\mathrm{N}, \mathrm{N}$-dimethyl- $\mathrm{N}^{\prime}-(1-$ methylimidazole-2-ylmethyl)-N'-(2-hydroxy-4-nitrobenzyl)ethylenediamine H(L4) (scheme 2) were synthesized according to known procedures, ${ }^{18,20}$ which involve simple substitution reactions. They may be regarded as derivatives of the exclusively pyridine containing ligand TPA. The pendant pyridine/imidazole functionality has been incorporated into the ligand to provide a systematic variation in the Lewis acidity of the iron(III) centre. The bulky N,N-dimethyl group, the pyridine ring nitrogen sterically hindered by 6methyl group and the more basic $\mathrm{N}$-methylimidazole moiety $\left[\mathrm{p} K_{a}\left(\mathrm{BH}^{+}\right)\right.$: imidazole, $6 \cdot 0$; pyridine, $\left.5 \cdot 2\right]$ in the ligands are expected to influence the iron(III) coordination structures as well as the electronic properties of the complexes and offer steric hindrance to the substrates so as to closely approximate the active site in enzyme-substrate complexes. The tetradentate ligands provide a reasonable analogue to histidine and tyrosinate coordination in CTD and PCD enzymes via the heterocyclic nitrogen donors and phenolate moieties respectively. The iron(III) complexes of the monophenolate ligands are formulated as $\left[\mathrm{Fe}(\mathrm{L} 1) \mathrm{Cl}_{2}\right] \cdot \mathrm{CH}_{3} \mathrm{CN}(\mathbf{1}),\left[\mathrm{Fe}(\mathrm{L} 2) \mathrm{Cl}_{2}\right]$ (2), 
[Fe( $\left.\mathrm{L} 3) \mathrm{Cl}_{2}\right](3)$ and $\left[\mathrm{Fe}(\mathrm{L} 4) \mathrm{Cl}_{2}\right](4)$, which is supported by the X-ray crystal structures of $\mathbf{1}$ and $\mathbf{2}$ (cf. below).

The bisphenolate ligands $\mathrm{N}, \mathrm{N}$-dimethyl- $\mathrm{N}^{\prime}, \mathrm{N}^{\prime}-$ bis(2-hydroxy-3,5-dimethyl-benzyl)ethylenediamine [ $\left.\mathrm{H}_{2}(\mathrm{~L} 5)\right], \quad \mathrm{N}, \mathrm{N}$-dimethyl- $\mathrm{N}^{\prime}, \mathrm{N}^{\prime}$-bis(2-hydroxy-4-nitrobenzyl)ethylenediamine $\left[\mathrm{H}_{2}(\mathrm{~L} 6)\right], \quad \mathrm{N}, \mathrm{N}^{\prime}$-dimethyl$\mathrm{N}, \mathrm{N}^{\prime}$-bis(2-hydroxy-3,5-dimethylbenzyl)-ethylenediamine $\left[\mathrm{H}_{2}(\mathrm{~L} 7)\right]$ and $\mathrm{N}, \mathrm{N}^{\prime}$-dimethyl-N, $\mathrm{N}^{\prime}$-bis(2hydroxy-4-nitrobenzyl)ethylenediamine $\quad\left[\mathrm{H}_{2}(\mathrm{~L} 8)\right]$ (scheme 2) were synthesised according to known procedures, which involve Mannich condensation and simple substitution reactions. ${ }^{19,21}$ The complexes of $\left[\mathrm{H}_{2}(\mathrm{~L} 5)\right]$ and $\left[\mathrm{H}_{2}(\mathrm{~L} 7)\right]$ are formulated as $[\mathrm{Fe}(\mathrm{L} 5) \mathrm{Cl}]$ 5 and $[\mathrm{Fe}(\mathrm{L} 7) \mathrm{Cl}] 7$ while those of $\left[\mathrm{H}_{2}(\mathrm{~L} 6)\right]$ and $\left[\mathrm{H}_{2}(\mathrm{~L} 8)\right]$ as $\left[\mathrm{Fe}(\mathrm{L} 6)\left(\mathrm{H}_{2} \mathrm{O}\right) \mathrm{Cl}\right] \mathbf{6}$ and $\left[\mathrm{Fe}(\mathrm{L} 8)\left(\mathrm{H}_{2} \mathrm{O}\right) \mathrm{Cl}\right]$ $\mathbf{8}$, which is supported by the $\mathrm{X}$-ray crystal structures of 5 and $\mathbf{6}$ (cf. below).

\section{Description of the $\mathrm{X}$-ray crystal structures of $\left[\mathrm{Fe}(\mathrm{L1}) \mathrm{Cl}_{2}\right] . \mathrm{CH}_{3} \mathrm{CN}, 1,\left[\mathrm{Fe}(\mathrm{L2}) \mathrm{Cl}_{2}\right], 2$, $[\mathrm{Fe}(\mathrm{L5}) \mathrm{Cl}], 5$ and $\left[\mathrm{Fe}(\mathrm{L6})\left(\mathrm{H}_{2} \mathrm{O}\right) \mathrm{Cl}\right], 6$}

Both the complex molecules $\left[\mathrm{Fe}(\mathrm{L} 1) \mathrm{Cl}_{2}\right] \cdot \mathrm{CH}_{3} \mathrm{CN}, \mathbf{1}$ and $\left[\mathrm{Fe}(\mathrm{L} 2) \mathrm{Cl}_{2}\right], 2$ have a $\mathrm{FeN}_{3} \mathrm{OCl}_{2}$ coordination sphere<smiles>O=[N+]([O-])c1ccc(O)c(CN(Cc2ccccn2)Cc2ccccn2)c1</smiles>

$H(L 1)$<smiles>Cc1cccc(CN(CCN(C)C)Cc2cc([N+](=O)[O-])ccc2O)n1</smiles>
$H(L 3)$<smiles>[R6]c1cc(Br)c(O)c(CN(CCN(C)C)Cc2cc([R6])cc(Br)c2O)c1</smiles>
$\begin{array}{lcc} & \mathrm{R}_{1} & \mathrm{R}_{2} \\ \mathrm{H} 2(\mathrm{~L} 5) & \mathrm{CH}_{3} & \mathrm{CH}_{3} \\ \mathrm{H} 2 \text { (L6) } & \mathrm{H} & \mathrm{NO}_{2}\end{array}$

Scheme 2. Structures of the mono- and bisphenolate ligands. with a distorted octahedral geometry, constituted by three nitrogen atoms and one phenolate oxygen atom from the tripodal ligand and two chloride ions. In 2 the $\mathrm{Fe}-\mathrm{N} 3$ bond is significantly longer than the $\mathrm{Fe}-$ $\mathrm{N} 2$ bond due to the inability of the sterically hindering $-\mathrm{NMe}_{2}$ group to properly orient itself towards iron(III). The observed Fe-O1 distance (1.929 $\AA$ ) is shorter ${ }^{17-19}$ than the average octahedral $\mathrm{Fe}^{\mathrm{III}}-\mathrm{O}$ distance of $\sim 1.98 \AA$ suggesting strong iron-oxygen overlap. $^{22}$ The phenolate oxygen in the six-membered chelate ring has a $\mathrm{Fe}-\mathrm{O} 1-\mathrm{C} 13$ bond angle of $136 \cdot 1^{\circ}$, which is higher than the ideal value of $120^{\circ}$ for $s p^{2}$ hybridized phenolate oxygen atom indicating that the latter (in-plane $p \pi$ orbital) interacts less strongly with a half-filled $d \pi^{*}$ orbital on iron(III). Also, the angle is higher than the average $\mathrm{Fe}-\mathrm{O}-\mathrm{C}$ bond angle of $\sim 128.5^{\circ}$ observed in other octahedral iron(III)phenolate complexes. ${ }^{17-19,22,23}$

A comparison of the structural parameters of $\mathbf{2}$ with those of $1 . \mathrm{CH}_{3} \mathrm{CN}$ reveals remarkable differ-

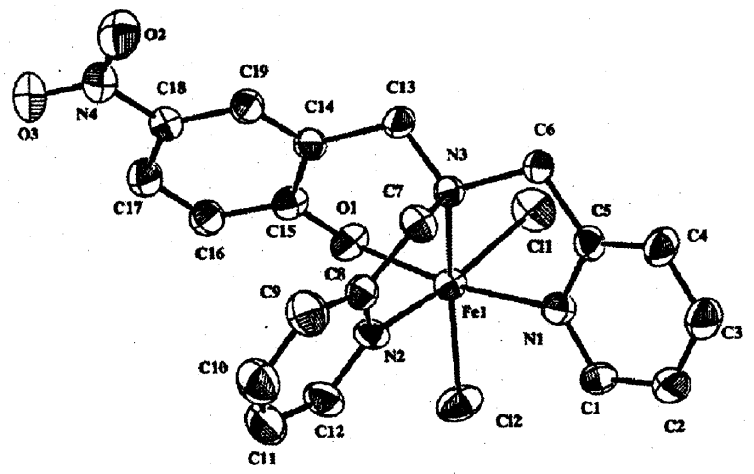

$\left[\mathrm{Fe}(\mathrm{L} 1) \mathrm{Cl}_{2}\right] \cdot \mathrm{CH}_{3} \mathrm{CN} \mathrm{I}$

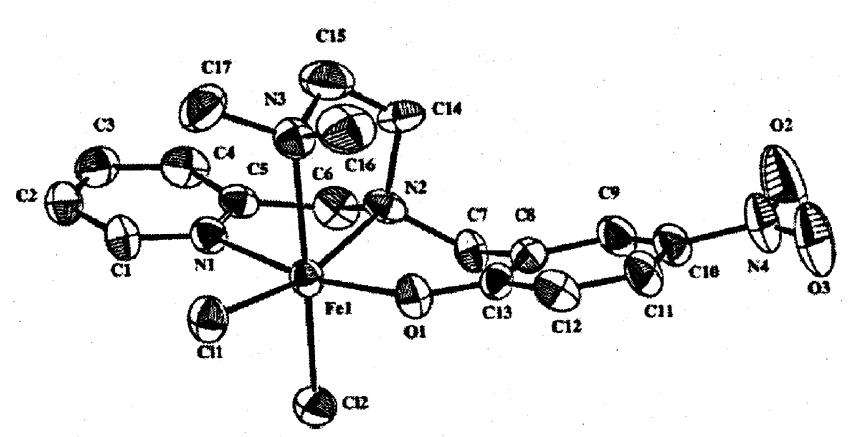

$\left[\mathrm{Fe}(\mathrm{L} 2) \mathrm{Cl}_{2}\right] 2$

Figure 1. Structures of $\left[\mathrm{Fe}(\mathrm{L} 1) \mathrm{Cl}_{2}\right] \cdot \mathrm{CH}_{3} \mathrm{CN} \mathbf{1}$ and $\left[\mathrm{Fe}(\mathrm{L} 2) \mathrm{Cl}_{2}\right] 2$ showing the atom numbering scheme and the thermal motion ellipsoids (50\% probability level) for the non-hydrogen atoms. 
ences in their structures. The replacement of one of the pyridine pendants in $1 . \mathrm{CH}_{3} \mathrm{CN}$ by the sterically demanding $-\mathrm{NMe}_{2}$ group to obtain 2 results in shortening of $\mathrm{Fe}-\mathrm{N}$ but elongation of $\mathrm{Fe}-\mathrm{Cl}$ bonds. The replacement of pyridine moiety in $1 . \mathrm{CH}_{3} \mathrm{CN}$ by the sterically demanding $-\mathrm{NMe}_{2}$ group enhances the Fe$\mathrm{O}-\mathrm{C}$ bond angle from $128.5^{\circ}$ to $136 \cdot 1^{\circ}$ but decreases the $\mathrm{Fe}-\mathrm{O}-\mathrm{C}-\mathrm{C}$ dihedral angle from $59 \cdot 0^{\circ}$ to $15 \cdot 2^{\circ}$. This enhances the $\pi$-back bonding, which involves the $d \pi$ orbitals of iron and the relatively low lying $\pi^{*}$ orbital (vs phenolate ion) of the weakly $\sigma$-bonding $p$-nitrophenolate, leading to a stronger $\mathrm{Fe}-\mathrm{O}$ bond. This illustrates the importance of extended $\pi$ delocalisation involving $p$-nitrophenolate and iron(III) $d$-orbitals.

The coordination environment around the iron atom in $[\mathrm{Fe}(\mathrm{L} 5) \mathrm{Cl}] \mathbf{5}$ is described as distorted trigonal bipyramidal. The metal is bonded to two phenolate oxygens (O1, O2) and the amine nitrogen (N2) of the tripodal ligand, which define the trigonal plane of the bipyramid, and the other amine nitrogen

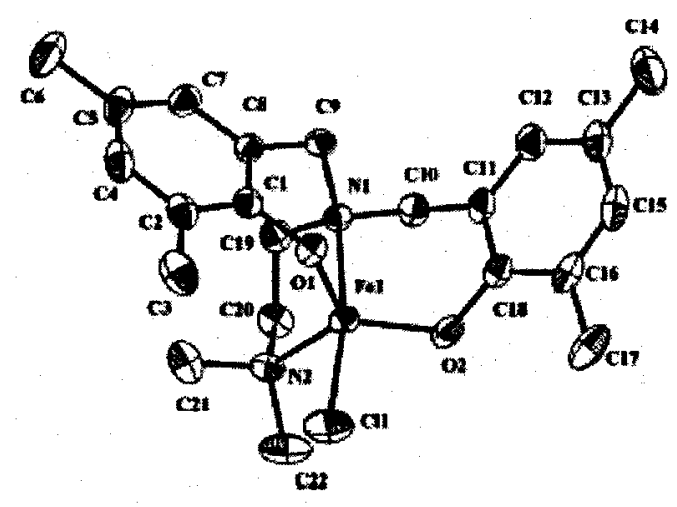

$[\mathrm{Fe}(\mathrm{L} 5) \mathrm{Cl}] \mathrm{5}$

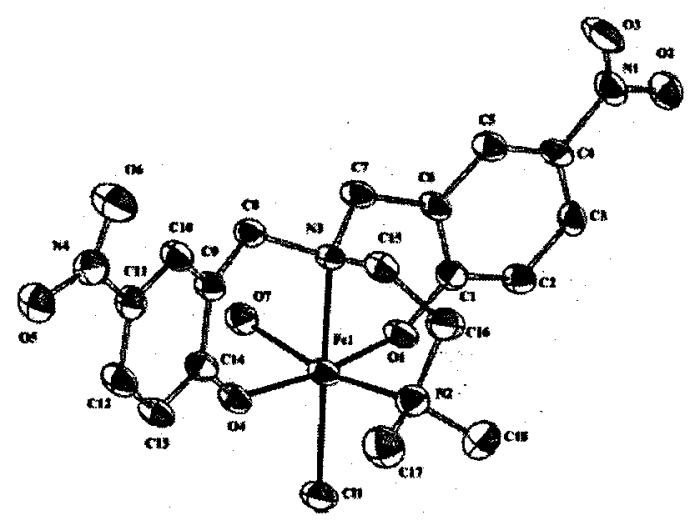

$\left[\mathrm{Fe}(\mathrm{L} 6)\left(\mathrm{H}_{2} \mathrm{O}\right) \mathrm{Cl}\right] 6$

Figure 2. Structures of $[\mathrm{Fe}(\mathrm{L} 5) \mathrm{Cl}] \mathbf{5}$ and $[\mathrm{Fe}(\mathrm{L} 6)$ $\left.\left(\mathrm{H}_{2} \mathrm{O}\right) \mathrm{Cl}\right] 6$ showing the atom numbering scheme and the thermal motion ellipsoids (50\% probability level) for the non-hydrogen atoms.
(N1) and chloride ion occupy the apical sites. The observed $\mathrm{Fe}-\mathrm{O}$ bond distances $(\mathrm{Fe}-\mathrm{O} 1,1 \cdot 867$; Fe$\mathrm{O} 2,1.855 \AA$ ) in 5 are shorter ${ }^{17-19}$ than the average octahedral $\mathrm{Fe}-\mathrm{O}$ bond distance of $1.92 \AA$ implying relatively strong iron-oxygen overlap, ${ }^{22}$ which is consistent with the lower coordination number. The $\mathrm{Fe}-\mathrm{O}-\mathrm{C}$ bond angles $(\mathrm{Fe}-\mathrm{O} 1-\mathrm{C} 1,122.05$; $\mathrm{Fe}-\mathrm{O} 2-$ $\left.\mathrm{C} 18,122 \cdot 15^{\circ}\right)$ are much less than those in octahedral iron(III) complexes of phenolate ligands $\left(\sim 128.5^{\circ}\right)$ but are closer to the ideal value of $120^{\circ}$ for $s p^{2}$ hybridized phenolate oxygen atom suggesting that the latter interacts ${ }^{22}$ more strongly with a half-filled $d \pi^{*}$ orbital in iron(III) in the present complexes the coordination geometry around iron(III) is trigonal bipyramidal with the trigonality index $\tau$ of 0.79 $\left[\tau=(\beta-\alpha) / 60\right.$, where $\beta, \mathrm{N} 1-\mathrm{Fe}-\mathrm{Cl} 1=170 \cdot 14^{\circ}$ and $\alpha, \mathrm{O} 1-\mathrm{Fe}-\mathrm{N} 2=123.05^{\circ}$; for perfect square pyramidal and trigonal bipyramidal geometries the $\tau$ values are zero and unity respectively]. Interestingly, this coordination environment is closely related to the trigonal bipyramidal metal core $(\tau, 0.44)$ in the substrate-free 3,4-PCD enzyme; however, both the phenolates are equatorial in $\mathbf{5}$, while they are mixed axial-equatorial in the enzyme active site.

The complex $\left[\mathrm{Fe}(\mathrm{L6})\left(\mathrm{H}_{2} \mathrm{O}\right) \mathrm{Cl}\right] 6$ exhibits distorted octahedral coordination geometry constituted by two trans-coordinated phenolate oxygen atoms $(\mathrm{O} 1, \mathrm{O} 4)$ and the cis-coordinated amine nitrogen atoms (N2, N3) of the tetradentate ligand. One water molecule (O7) and a chloride ion occupy the remaining cispositions. The trans-disposed $\mathrm{Fe}-\mathrm{O}$ (phenolate) bonds are significantly different $(\mathrm{Fe}-\mathrm{O} 1,1.890 ; \mathrm{Fe}-\mathrm{O} 4$, $1.993 \AA$ ) but are similar to those in the previously reported $^{17-19,22,24}$ six-coordinated iron(III) complexes. This indicates the ability of the tripodal ligand to impose a difference in $\mathrm{Fe}-\mathrm{O}$ bond lengths in spite of the similarity in the phenolate oxygen atoms. This is interesting because the difference in the two Fe-tyrosinate bonds in the 3,4-PCD enzyme is thought to influence the asymmetric binding of the chelated substrate moiety. The $\mathrm{Fe}-\mathrm{O}-\mathrm{C}$ bond angles $\left(\mathrm{Fe}-\mathrm{O} 1-\mathrm{C} 1,135 \cdot 3 ; \mathrm{Fe}-\mathrm{O} 4-\mathrm{C} 14,135 \cdot 6^{\circ}\right)$ are similar to those in $\mathbf{2}$ but greater than those in $\mathbf{1}$ and $\mathbf{5}$ and other octahedral iron(III) complexes of phenolate ligands $\left(\sim 128.5^{\circ}\right)$ obviously due to the difference in phenolate substitution in the ligands; the dimethyl substituents on the phenolate moieties in $\mathbf{5}$ appear to provide no steric hindrance as revealed by spacefilling models, but electronic effects to stabilize the $\mathrm{Fe}-\mathrm{O}$ (phenolate) coordination and hence the trigonal bipyramidal coordination geometry. 
The Fe-Cl (2.271-2.339 ̊) bond distances in 1, 2 and $\mathbf{6}$ are in the same range as those for octahedral iron(III) complexes. ${ }^{17-19,22}$ The difference in bond lengths of cis chloride ions would encourage asymmetric bidentate coordination of the catecholate substrates, which is essential for substrate activation, subsequent reaction with molecular oxygen and removal. This is relevant to the 4-HBA-PCD complex (4-HBA = 4-hydroxybenzoate) in which a doubly deprotonated form of 4-HBA is chelated. ${ }^{25}$ Interestingly, there is only one $\mathrm{Fe}-\mathrm{Cl}$ bond in $\mathbf{5}$. This is interesting in view of the failure of this complex to catalyse the intradiol-cleavage (cf. below).

\section{Electronic absorption spectra}

The iron(III) monophenolate complexes 1-4 display the relatively intense band in the $535-550 \mathrm{~nm}$ region, which is assigned to phenolate $(\pi) \rightarrow \mathrm{Fe}(\mathrm{III})$ $\left(d \pi^{*}\right)$ ligand to metal charge-transfer (LMCT) transition. ${ }^{26,27}$ On the other hand, the high energy band observed in the $425-435 \mathrm{~nm}$ range is assigned ${ }^{26}$ to phenolate $(\sigma) \rightarrow \mathrm{Fe}(\mathrm{III})\left(d_{x^{2}-y^{2}} / d_{z^{2}}\right)$ ligand to metal charge transfer transition. The band energy of the lowest energy LMCT band decreases in the order $\mathbf{4}>\mathbf{2}>\mathbf{1}>\mathbf{3}$, reflecting the increase in Lewis acidity of the iron(III) centre in this order. On replacing the py moiety in 1 by the less strongly binding and sterically hindering $-\mathrm{NMe}_{2}$ group as in $\mathbf{2}$ the Lewis acidity increases. The negative charge built ${ }^{13}$ on iron(III) on replacing the py moiety in $\mathbf{2}$ by the more basic $\mathrm{N}$-methylimidazole moiety to obtain 4 raises the iron $d$-orbital energy, leading to the higher LMCT band energy for 4. Similarly, the incorporation of the sterically demanding 6-Me group in 2 to obtain $\mathbf{3}$ would hinder the coordination of py nitrogen leading to a decrease in negative charge built on iron(III) and hence the lower LMCT band energy for 3. Thus the Lewis acidity of the iron(III) centre is fine-tuned by modifying the ligand environment through the replacement of py moiety by imidazole moiety and suitable incorporation of methyl groups on the heterocyclic rings.

Two new visible bands $(480-490,635-800 \mathrm{~nm}$, table 1), which appear on adding catecholate dianions, are assignable to catecholate-to-Fe(III) LMCT transition ${ }^{28}$ involving two different catecholate orbitals on the chelated catecholate. The position of the low rather than high energy LMCT band of the catecholate adducts shows remarkable dependence on the nature of the primary ligand ${ }^{13-15,29,32}$ and, in fact, the magnitude of the energy of this band represents the Lewis acidity of the iron(III) centre as modified by the phenolate ligands. The low energy band of all the catecholates are shifted to lower energies on replacing the py moiety in $[\mathrm{Fe}(\mathrm{L} 1)(\mathrm{DBC})]$ by the less strongly binding and sterically hindering $-\mathrm{NMe}_{2}$ group as in $[\mathrm{Fe}(\mathrm{L} 2)(\mathrm{DBC})]$ illustrating the importance of steric rather than electronic factors of the phenolate ligands. Similarly, on incorporating the sterically hindering 6-Me substituent as in $[\mathrm{Fe}(\mathrm{L} 3)$ $(\mathrm{DBC})]$ the band is shifted to lower wavelength. Further, on replacing the py moiety in $[\mathrm{Fe}(\mathrm{L} 2)(\mathrm{DBC})]$ by the strongly $\sigma$-bonding $N$-methyl-imidazole moiety to obtain $[\mathrm{Fe}(\mathrm{L} 4)(\mathrm{DBC})]$ the band is shifted ${ }^{17}$ to higher energy revealing that electronic effects are critical in catecholate adduct formation.

In the iron(III) bisphenolate complexes 5-8 the band in the range $335-430 \mathrm{~nm}$ is assigned to the charge transfer transition from the out-of-plane $p \pi$ orbital (HOMO) of the phenolate oxygen to the halffilled $d_{x^{2}-y^{2}} / d_{z^{2}}$ orbital of iron(III). The lowest energy band $(475-550 \mathrm{~nm})$ would arise from the charge transfer transition ${ }^{24,26,27}$ from the in-plane $p \pi$ orbital (POMO) of the phenolate ion to the half-filled $d \pi^{*}$ orbital of iron(III). The shift of both these LMCT bands to lower energy is observed, on replacing the methyl groups in $\mathbf{5}$ by the electron-withdrawing $p$ nitro group ${ }^{24}$ to obtain $\mathbf{6}$. This reflects the lower Lewis acidity of the iron centre in $\mathbf{5}$ compared to $\mathbf{6}$, which is supported by the shorter and hence stronger $\mathrm{Fe}-\mathrm{O}$ bonds found in $\mathbf{5}$. The iron $d$-orbital energy in 6 is raised by the negative charge built ${ }^{30}$ on $\mathrm{Fe}$ (III) by the stronger $\mathrm{Fe}-\mathrm{O}$ (phenolate) bonds, as discussed above. Similar to $\mathbf{6}$, the introduction of $p$ nitro group shifts the highest energy LMCT band in $\mathbf{7}$ to lower energy in 8; however, the low energy LMCT band $(550 \mathrm{~nm})$ is shifted to higher energy $(515 \mathrm{~nm})$. Further, the tripodal ligand complexes 5 and 6 exhibit the LMCT band at energies higher than their respective linear ligand complexes $\mathbf{7}$ and $\mathbf{8}$.

On adding catecholate anions to $\mathbf{6}$ and $\mathbf{8}$ two new catecholate $\rightarrow \mathrm{Fe}$ (III) CT bands are observed. ${ }^{28}$ The blue shift of the high energy band indicates the conversion of $\mathrm{DBC}^{2-}$ ligand to a fairly basic ligand, which would be consistent with peroxide species in the proposed substrate activation mechanism for intradiol-cleavage mechanism. ${ }^{31}$ In contrast to $\mathbf{6}$ and 8, only one catecholate-to-Fe(III) LMCT band at a lower energy $(475-540 \mathrm{~nm})$ is obtained for 5 on the addition of catecholates. Also, the trend observed in the position of the band reflects the steric crowding 
Table 1. Electronic spectral data, redox potential, kinetic data and percentage yield of cleavage products of iron(III) complexes ${ }^{18,19}$

\begin{tabular}{|c|c|c|c|c|c|}
\hline \multirow[b]{2}{*}{ Complex } & \multirow{2}{*}{$\begin{array}{c}\lambda_{\max }, \mathrm{nm} \\
\left(\varepsilon, \mathrm{M}^{-1} \mathrm{~cm}^{-1}\right)\end{array}$} & \multicolumn{2}{|c|}{$E_{1 / 2}(\mathrm{~V})$} & \multirow[b]{2}{*}{$k_{\mathrm{O} 2}\left(\mathrm{M}^{-1} \mathrm{~s}^{-1}\right)$} & \multirow[b]{2}{*}{ (\% yield) } \\
\hline & & $\mathrm{CV}^{\mathrm{c}}$ & DPV & & \\
\hline$\left[\mathrm{Fe}(\mathrm{L} 1) \mathrm{Cl}_{2}\right]$ & $\begin{array}{l}540(3200) \\
435(2325)\end{array}$ & $-0 \cdot 294$ & $-0 \cdot 297$ & & \\
\hline$[\mathrm{Fe}(\mathrm{L} 1)(\mathrm{DBC})]$ & $\begin{array}{l}780(3570) \\
490(3325)\end{array}$ & - & - & - & - \\
\hline$\left[\mathrm{Fe}(\mathrm{L} 2) \mathrm{Cl}_{2}\right]$ & $\begin{array}{l}535(3570) \\
430(3195)\end{array}$ & $-0 \cdot 262$ & $-0 \cdot 266$ & & \\
\hline$[\mathrm{Fe}(\mathrm{L} 2)(\mathrm{DBC})]$ & $\begin{array}{l}790(3260) \\
490(3325)\end{array}$ & - & - & $4 \cdot 6 \times 10^{-3}$ & $60 \cdot 3$ \\
\hline$\left[\mathrm{Fe}(\mathrm{L} 3) \mathrm{Cl}_{2}\right]$ & $\begin{array}{l}550(3190) \\
365(13890)\end{array}$ & $-0 \cdot 176$ & $-0 \cdot 152$ & & \\
\hline$[\mathrm{Fe}(\mathrm{L} 3)(\mathrm{DBC})]$ & $\begin{array}{l}800(3465) \\
495(3265)\end{array}$ & - & - & - & - \\
\hline$\left[\mathrm{Fe}(\mathrm{L} 4) \mathrm{Cl}_{2}\right]$ & $\begin{array}{l}535(3570) \\
425(3645)\end{array}$ & $-0 \cdot 278$ & $-0 \cdot 280$ & & \\
\hline$[\mathrm{Fe}(\mathrm{L} 4)(\mathrm{DBC})]$ & $\begin{array}{l}760(2630) \\
490(3085)\end{array}$ & - & - & $2.9 \times 10^{-2}$ & $83 \cdot 0$ \\
\hline$[\mathrm{Fe}(\mathrm{L} 5) \mathrm{Cl}]$ & $475(4530)$ & -0.495 & -0.483 & & \\
\hline $\begin{array}{l}{[\mathrm{Fe}(\mathrm{L} 5)(\mathrm{DBC})]} \\
{\left[\mathrm{Fe}(\mathrm{L} 6)\left(\mathrm{H}_{2} \mathrm{O}\right) \mathrm{Cl}\right]}\end{array}$ & $\begin{array}{l}540(4530) \\
515(3530)\end{array}$ & $\begin{array}{l}-0 \cdot 320 \\
-0 \cdot 202\end{array}$ & $\begin{array}{l}-0 \cdot 313 \\
-0 \cdot 205\end{array}$ & - & - \\
\hline$[\mathrm{Fe}(\mathrm{L} 6)(\mathrm{DBC})]$ & $\begin{array}{l}430(5510) \\
700(15970) \\
410(14780)\end{array}$ & $\begin{array}{l}-0.495 \\
-0 \cdot 101\end{array}$ & $-0 \cdot 525$ & $3 \cdot 8 \times 10^{-3}$ & 100 \\
\hline$[\mathrm{Fe}(\mathrm{L} 7) \mathrm{Cl}]$ & $\begin{array}{l}550(2820) \\
340(4360)\end{array}$ & & $-0 \cdot 581$ & & \\
\hline$[\mathrm{Fe}(\mathrm{L} 7)(\mathrm{DBC})]$ & $\begin{array}{l}545(2670) \\
470(2480)\end{array}$ & $-0 \cdot 394$ & $\begin{array}{l}-0 \cdot 883 \\
-0 \cdot 395\end{array}$ & - & - \\
\hline$\left[\mathrm{Fe}(\mathrm{L} 8)\left(\mathrm{H}_{2} \mathrm{O}\right) \mathrm{Cl}\right]$ & $\begin{array}{l}515(4860) \\
425(8250)\end{array}$ & $-0 \cdot 354$ & $-0 \cdot 345$ & & \\
\hline$[\mathrm{Fe}(\mathrm{L} 8)(\mathrm{DBC})]$ & $\begin{array}{c}690(2015) \\
410(25000)\end{array}$ & $-0 \cdot 191$ & $\begin{array}{l}-0 \cdot 763 \\
-0 \cdot 189\end{array}$ & Very fast & - \\
\hline
\end{tabular}

and electronic effects provided by the catechols on binding to 5 . Further, for 7 also only one but blueshifted $(5-85 \mathrm{~nm})$ LMCT band is observed. This is interesting in view of the failure of 5 and $\mathbf{7}$ to catalyse the intradiol-cleavage (cf. below).

\section{Redox behaviour}

The electrochemical behaviour of the iron(III) monoand bis-phenolato complexes were studied by employing cyclic (CV) and differential pulse voltammetry (DPV) using a stationary platinum sphere as working electrode and a non-aqueous $\mathrm{Ag} / \mathrm{Ag}^{+}$electrode as reference. In methanol solution all the mono-phenolato complexes exhibit completely irreversible redox behaviour with a cathodic wave in the range 0.090-0.258 $\mathrm{V}$ (table 1 ), but with no anodic wave. All the bis-phenolato complexes show a ca- thodic wave in the range $-0 \cdot 244$ to $-0 \cdot 660 \mathrm{~V}$ (table 1) and only the complexes $\mathbf{6}$ and $\mathbf{8}$ show the corresponding anodic wave $(\mathbf{2},-0 \cdot 160 ; \mathbf{8},-0.308 \mathrm{~V})$. For all the complexes, the plots of $i_{p c}$ vs $v^{1 / 2}\left(v<0.5 \mathrm{Vs}^{-1}\right)$ are linear, revealing a diffusion controlled redox process. The values of diffusion coefficients $(\mathrm{D}, 1.5$ $-6.8 \times 10^{-6} \mathrm{~cm}^{2} / \mathrm{s}$ ) calculated by assuming reversibility fall in the range observed for other iron(III) complexes. ${ }^{17}$ The $\mathrm{Fe}^{\mathrm{III}} / \mathrm{Fe}^{\mathrm{II}}$ redox potentials of the mono-phenolato complexes 1-4 are more negative than that for $\left[\mathrm{Fe}(\mathrm{TPA}) \mathrm{Cl}_{2}\right] \mathrm{Cl}$ complex ${ }^{17}$ and those of bis-phenolato complexes 5-8 are more negative than the former illustrating that incorporation of iron(III)phenolate bond stabilizes the iron(III) oxidation state.

The $E_{1 / 2}$ values of $\mathrm{Fe}^{\mathrm{III}} / \mathrm{Fe}^{\mathrm{II}}$ redox potentials of the monophenolato complexes follow the trend $\mathbf{3}>\mathbf{2}>$ $4>1$, which represents the decrease in Lewis acidity 


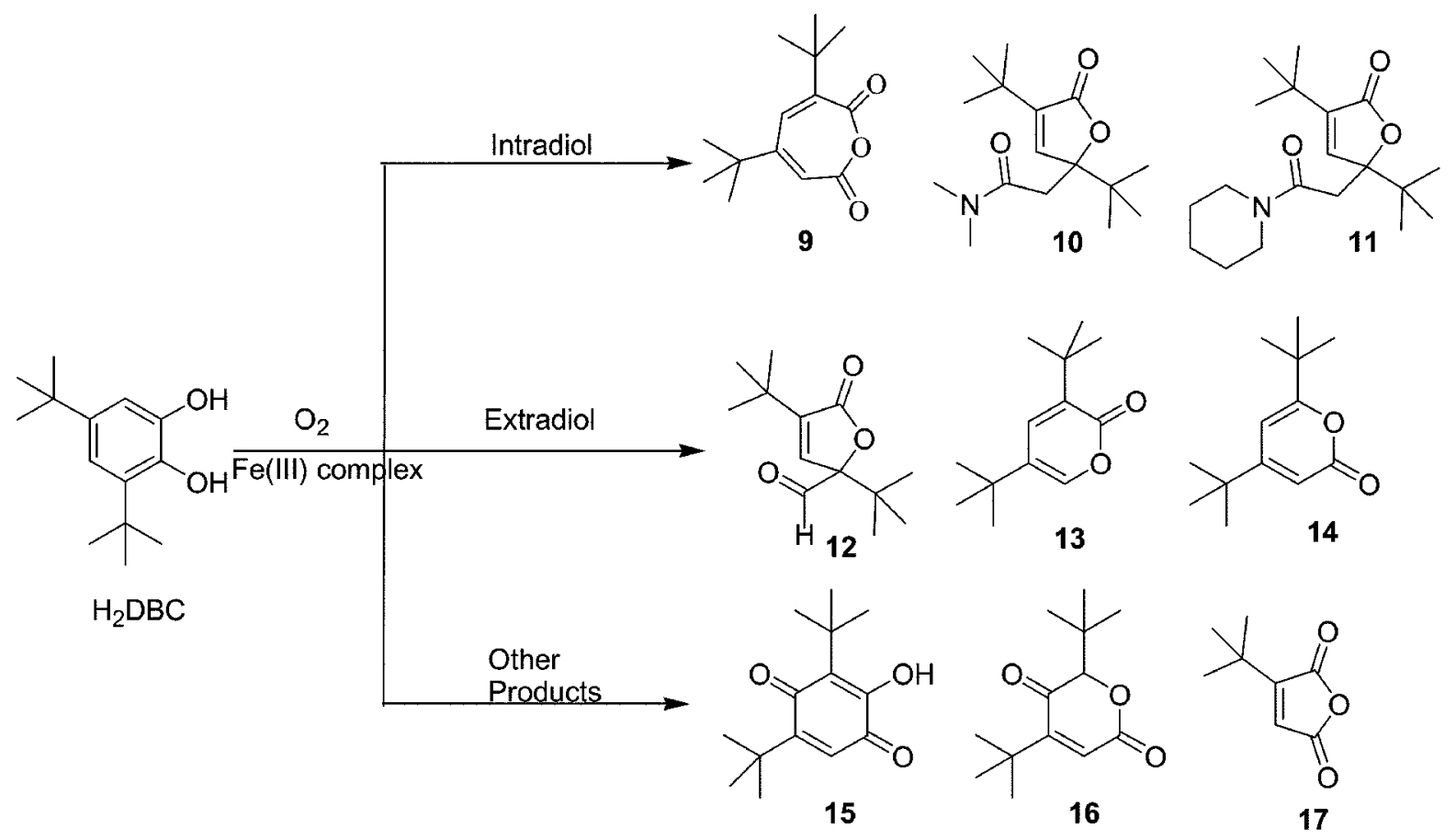

Scheme 3. Cleavage products of $\mathrm{H}_{2} \mathrm{DBC}$ mediated by iron(III) complexes: 3,5-di-tert-butyl-1-oxacyclohepta3,5-diene-2,7-dione (9), 3,5-di-tert-butyl-5-(N,N-dimethylamidomethyl)-2-furanone (10), 3,5-di-tert-butyl-5-(2oxo-2-piperidinylethyl)-5H-furanone (11), 3,5-di-tert-butyl-5-formyl-2-furanone (12), 3,5-di-tert-butyl-2-pyrone (13), 4,6-di-tert-butyl-2-pyrone (14), 3,5-di-tert-butyl-2-hydroxy-1,4-benzoquinone (15), 2,5-di-tert-butyl-2Hpyran-3,6-dione (16), 3-tert-butylfuran-2,5-dione (17).

of the iron(III) centre, consistent with the above spectral results. On replacing the pyridyl arm in $\mathbf{1}$ by $-\mathrm{NMe}_{2}$ group to obtain 2 the iron(III) centre is destabilised due to weak $\sigma$-bonding interaction by the sterically demanding $-\mathrm{NMe}_{2}$ group (cf. above). Similarly, on introducing the sterically hindering 6methyl group on the pyridyl ring in $\mathbf{2}$ to give $\mathbf{3}$, the iron(III) oxidation state is destabilised (cf. above). The Lewis basicity of $\mathrm{N}$-methylimidazole moiety in L4, which is higher than that of pyridine moiety in L2, leads to enhanced stabilization of iron(III) oxidation state in $\mathbf{4}$, rendering its $\mathrm{Fe}^{\mathrm{III}} / \mathrm{Fe}^{\mathrm{II}}$ redox potential more negative. The $E_{1 / 2}$ values for $\mathrm{Fe}^{\mathrm{III}} / \mathrm{Fe}^{\mathrm{II}}$ couple of 5-8 exhibit the following trends: $\mathbf{5}<\mathbf{6}$, $\mathbf{7}<\mathbf{8}$; this reflects the increase in Lewis acidity of the iron(III) centre as the electron-releasing methyl groups on the phenolate donors are replaced by the $p-\mathrm{NO}_{2}$ group. The trend in Lewis acidity of $\mathbf{5}$ and $\mathbf{6}$ is consistent with that derived from $\mathrm{PhO}^{-} \rightarrow \mathrm{Fe}(\mathrm{III})$ LMCT band energies. Interestingly, the redox potentials of linear ligand complexes $\mathbf{6}$ and $\mathbf{8}$ are more negative than the respective tripodal ligand complexes 5 and 7. This is consistent with the trend observed in the energies of LMCT bands and suggests that linear ligands are more suitable than tripodal ligands to strongly bind to and hence confer decreased Lewis acidity on iron(III) centre. The appearance of the $\mathrm{DBC}^{2-} \rightarrow \mathrm{Fe}$ (III) LMCT band and DBSQ/DBC ${ }^{2-}$ redox wave and the lowering of the $\mathrm{Fe}(\mathrm{III}) / \mathrm{Fe}(\mathrm{II})$ redox potential on adding $\mathrm{H}_{2} \mathrm{DBC}$ even in the absence of added base illustrate the spontaneous deprotonation of the latter on binding to iron(III).

\section{Catechol 1,2-dioxygenase activity}

The 3,5-di-tert-butylcatecholate $\left(\mathrm{DBC}^{2-}\right)$ adducts of the present complexes were generated in situ in DMF solution and their reactivity towards $\mathrm{O}_{2}$ was investigated by monitoring the decay of $\mathrm{DBC}^{2-}$. Interestingly, only $\mathbf{2} \cdot \mathrm{DBC}^{2-}, \mathbf{4} \cdot \mathrm{DBC}^{2-}, \mathbf{6} \cdot \mathrm{DBC}^{2-}$ and $\mathbf{8}$. $\mathrm{DBC}^{2-}$ were found to react. While $\mathbf{8}$ reacted very fast, the other complexes exhibit a pseudo-first-order kinetics due to excess of dioxygen used, as judged from the linearity of the plot of $[1+\log (\mathrm{Abs})]$ vs time. The rates of the reactions (table 1) were calculated $^{30,32}$ by using the equation, 


$$
k_{\mathrm{O}_{2}}=k_{\mathrm{obs}} / \mathrm{O}_{2}
$$

Both GC and GC-MS techniques were used to identify and quantify the oxidative intradiol $(9,10,11$, table 1 , scheme 3 ) and very small amounts of extradiol (12-14) and side (15-17) products of $\mathrm{H}_{2} \mathrm{DBC}$. The products 10 and 11 are derived ${ }^{15}$ from the nucleophilic attack respectively of $\mathrm{Me}_{2} \mathrm{NH}$ as impurity in DMF and piperidine on cis,cis-muconic anhydride (9), which is the immediate product of oxidative cleavage. From the reaction mixture two intradiol $(\mathbf{9}, 61, \mathbf{1 0}, 25 \%)$ and one extradiol $(\mathbf{1 3}, 14 \%)$ cleavage products were identified for $\mathbf{6}$. In contrast, interestingly, only one intradiol cleavage product 9 was identified for $\mathbf{8}$.

Very low amounts of the extradiol products are expected because the six-coordinate catecholate adducts of 2, 4, 6 and 8 have no vacant coordination site for $\mathrm{O}_{2}$ to attack. ${ }^{25}$ Since mainly intradiol cleavage products were obtained, the oxidative reactions catalysed by the complexes correspond exclusively to intradiol-cleavage pathway; hence the trend in reactivity of these adducts may be illustrated by invoking the novel substrate-activation mechanism proposed $^{31,33,34}$ for the intradiol-cleaving dioxygenase enzymes. The incorporation of a coordinated phenolic hydroxyl group into $[\mathrm{Fe}(\mathrm{TPA})(\mathrm{DBC})]^{+}$ $\left(k_{\mathrm{O}_{2}}, 1.5 \times 10^{3} \mathrm{M}^{-1} \mathrm{~s}^{-1}\right)^{33}$ as in [Fe(HDP)(DBC)] $[\mathrm{H}(\mathrm{HDP})=2-[$ (bis (2-pyridylmethyl)-aminomethyl $]-$ 4,6-dimethylphenol $]^{14}$ decreases the Lewis acidity of the iron(III) centre and hence lowers the rate of dioxygenation enormously $\left(k_{\mathrm{O}_{2}}, 3.3 \times 10^{-3} \mathrm{M}^{-1} \mathrm{~s}^{-1}\right)$. On the other hand, the incorporation of $p$-nitrophenolate moiety as in $\mathbf{1}$ leads to lack of reactivity towards dioxygen and $\mathrm{H}_{2} \mathrm{O}_{2}$ as well. ${ }^{16}$ The $p$-nitrophenolate donor, as it is weakly $\sigma$-bonding, does not appear to facilitate the decomposition of the reaction intermediate into products (cf. above). Also, on replacing one of the pyridyl moieties in $\mathbf{1}$ by the $-\mathrm{NMe}_{2}$ pendant to obtain $\mathbf{2}$ the dioxygenase activity is restored; obviously, the weak coordination of the sterically hindering $-\mathrm{NMe}_{2}$ group (cf. above) enhances the Lewis acidity of the iron(III) centre sufficiently thereby increasing the reaction rate. Further, as previously demonstrated by Que ${ }^{13,14,33}$ and Palaniandavar, ${ }^{17-19}$ the higher Lewis acidity of the iron(III) centre in $\mathbf{2}$ (cf. above) would be expected to confer a higher rate of oxygenation on $2 \cdot \mathrm{DBC}^{2-}$. But, interestingly, the latter reacts $\left(k_{\mathrm{O}_{2}}, 2.9 \times 10^{-2} \mathrm{M}^{-1} \mathrm{~s}^{-1}\right)$ approximately six times slower than $4 \cdot \mathrm{DBC}^{2-}$ does $\left(k_{\mathrm{O}_{2}}, 4.6 \times 10^{-3} \mathrm{M}^{-1} \mathrm{~s}^{-1}\right)$, which is consistent with the former displaying a more efficient conversion of the substrate to intradiol products than the latter $(\mathbf{4}, \mathbf{1 0}$, $1.0 ; 11,52.6 \% ; 2: 10,1.5 ; 11,75.6 \%)$. The dissociation of the reaction intermediate into products, which is possibly the rate-determining phase of oxygenation reaction as for the enzymes, ${ }^{31}$ appears to be facilitated by the more basic N-methylimidazole moiety in $\mathbf{4}$, leading to the observed higher rate of catechol cleavage. Similar enhancement in rates have been observed by us ${ }^{19}$ and Krebs et $a l^{24}$ previously.

Further, on replacing the pendant py moiety in $\mathbf{2}$ by one more pendant $p$-nitrophenolate moiety to obtain 6 only a slight decrease in reaction rate is observed $\left(k_{\mathrm{O}_{2}}, 3.8 \times 10^{-3} \mathrm{M}^{-1} \mathrm{~s}^{-1}\right){ }^{19}$ This is consistent with the presence of trans-disposed and significantly different $(1.890,1.993 \AA)^{19} \mathrm{Fe}-\mathrm{O}$ ( $p$-nitrophenolate) bonds, which facilitate the unsymmetrical chelation $^{26}$ of catecholate and hence the release of products from reaction intermediates. ${ }^{13}$ A similar higher rate of cleavage and higher cleavage yield have been noted respectively by Krebs $e t a l^{24}$ and Palaniandavar et $a l^{17}$ for certain bis(phenolate)iron(III) complexes. Furthermore, the inactivity of $\mathbf{3}$ towards catechol cleavage, in spite of enhanced Lewis acidity of its iron(III) centre, is intriguing. The sterically high demanding 6-methyl group in this adduct appears to hinder the approach of dioxygen. A similar dioxygenation activity of $\left[\mathrm{Fe}(\mathrm{MeTPA}) \mathrm{Cl}_{2}\right]^{35}$ [MeTPA = (6-methylpyrid-2-ylmethyl)bis (pyrid-2ylmethyl)amine] extremely lower than $\left[\mathrm{Fe}(\mathrm{TPA}) \mathrm{Cl}_{2}\right] \mathrm{Cl}$ has been noticed previously.

The rate of the reaction calculated for $\mathbf{6}$ is $3.76 \times 10^{-3} \mathrm{M}^{-1} \mathrm{~s}^{-1}$ and 8 reacts very fast. The latter with a Lewis acidity lesser than the former (cf. above) would be expected to exhibit a lower rate of dioxygenase reaction. However, interestingly, 8 reacts much faster ${ }^{13}$ than 2 . Unlike the tripodal ligand complex $\mathbf{6}$, the linear tetradentate ligand in $\mathbf{8}$ should rearrange itself to provide cis-coordination positions for bidentate coordination of the catechol substrate. The increased steric congestion and the enhanced negative charge built on iron(III) in $8 . \mathrm{DBC}^{2-}$ compared to $6 \cdot \mathrm{DBC}^{2-}$ adduct would facilitate the ratedetermining product-releasing phase in the reaction mechanism proposed by Que et al for intradiolcleaving dioxygenases. Also it is relevant to note that the reactivities of iron(III) complexes of tetradentate tripodal ligands differ from those of tetradentate macrocyclic ligands. 


\section{Conclusions and relevance to iron oxygenases}

To conclude, the mononuclear iron(III) complexes of sterically hindered tripodal mono- and bis-phenolate ligands offering $\mathrm{N}_{3} \mathrm{O}$ and $\mathrm{N}_{2} \mathrm{O}_{2}$ donor sets have been studied as structural, spectral and functional models for the intradiol-cleaving catechol 1,2-dioxygenase enzymes. It is remarkable that suitably tailored sterically hindered and strongly Lewis basic-bis (phenolate) ligands can stabilize five-coordinate iron(III) geometries, which closely mimic the active site geometry of the intradiol-cleaving enzymes and confer interesting spectral and chemical properties. In the X-ray crystal structure of two of these complexes the tripodal ligands are coordinated to the iron(III) centre with a distorted octahedral coordination geometry. Interestingly, the $\mathrm{Fe}-\mathrm{O}-\mathrm{C}$ bond angle of $136.1^{\circ}$ observed for the complexes is higher than the average $\mathrm{Fe}-\mathrm{O}-\mathrm{C}$ bond angle of $\sim 128.5^{\circ}$ reported for other octahedral iron(III)-phenolate complexes. This structural feature, which originates from the other donors of the phenolate ligand, namely, the sterically demanding $-\mathrm{NMe}_{2}$ group, leads to an enhanced rate of catechol cleavage. This is relevant to the stereochemical constraints in the 3,4-PCD enzymes, the function of which is traced to the quite different equatorial and axial $\mathrm{Fe}-\mathrm{O}$ (tyrosinate) bond distances $(1 \cdot 81,1.91 \AA)$, as determined by the $\mathrm{Fe}-\mathrm{O}-$ $\mathrm{C}$ bond angles $\left(133,148^{\circ}\right)$ and $\mathrm{Fe}-\mathrm{O}-\mathrm{C}-\mathrm{C}$ dihedral angles $\left(68,24^{\circ}\right)$.

A noteworthy observation is that the substituents on the phenolate ligands tend to tune the Lewis acidity of the iron(III) centre and hence determine the course and products of dioxygenase activity of the complexes. Thus the ligand donor functionalities $-\mathrm{NMe}_{2}$, (6-methyl)pyridine and $\mathrm{N}$-methylimidazole exhibit different stereoelectronic effects in clearly influencing the shielding of the iron(III) centre and hence its Lewis acidity, as demonstrated by the spectral and electrochemical properties. It is remarkable that the imidazole-based complex confers enhanced reaction rate with efficient conversion of substrate to intradiol cleavage products. The rates of dioxygenase reaction of the complexes could be illustrated not on the basis of the Lewis acidity of the iron(III) centre alone but by assuming that product release is the rate-determining phase of the catalytic reaction, lending support to the electron-transfer mediated substrate activation mechanism proposed by Que and coworkers.

\section{Acknowledgments}

We sincerely thank the Department of Science and Technology, New Delhi for supporting this research. We thank Prof. CNR Rao, FRS and Dr GU Kulkarni, Jawaharlal Nehru Center for Advanced Scientific Research, Bangalore 560012 for kindly providing the diffractometer facility.

\section{References}

1. (a) Solomon E I 2001 Inorg. Chem. 40 3656; (b) Que L Jr and Ho R Y N 1996 Chem. Rev. 96 2607; (c) Feig A L and Lippard S J 1994 Chem. Rev. 94759

2. (a) Solomon E I, Brunold T C, Davis M I., Kemsley J N, Lee S K, Lehnert N, Neese F, Skulan A J, Yang Y S and Zhou J 2000 Chem. Rev. 100 235; (b) Du Bois J, Mizoguchi T J and Lippard S J 2000 Coord. Chem. Rev. 200-202 443; (c) Que Jr L, Heistand II R H, Mayer R and Roe A L 1980 Biochemistry 192588

3. (a) Chen K, Costas M and Que Jr L 2002 J. Chem. Soc., Dalton Trans. 672; (b) Merkx M, Kopp D A, Sazinsky M H, Blazyk J L, Muller J and Lippard S J 2001 Angew. Chem. Int. Ed. 40 2782; (c) Que Jr L and Dong Y 1996 Acc. Chem. Res. 29 190; (d) Heistand II R H, Laufer R B, Fikrig E and Que Jr L 1982 J. Am. Chem. Soc. 1042789

4. (a) Bugg T D H 2001 Curr. Opin. Chem. Biol. 5 550; (b) Feeney R E and Komatsu S S 1996 Struct. Bonding (Berlin) 1 149; (c) Ainscough E W and Gainsford A R 1980 Inorg. Chem. 193655

5. (a) Bugg T D H and Winfield C J 1998 Natl. Prod. Rep. 15 513; (b) Reineke W and Knackmuss M J 1988 Annu. Rev. Microbiol. 42 263; (c) Dagley S 1975 Essays Biochem. 1181

6. Lange S J and Que Jr L 1998 Curr. Opin. Chem. Biol. 2 159; (b) Gibson D T (ed.) 1984 Microbial degradation of organic molecules (New York: Marcel Dekker) p. 535

7. (a) Que Jr L and Reynolds M F 2000 Metal Ions Biol. Syst. 37 505; (b) Hayaishi O, Katagiri $M$ and Rothberg S 1955 J. Am. Chem. Soc. 77 5450; (c) Kojima Y, Itada N and Hayaishi O $1961 \mathrm{~J}$. Biol. Chem. 236 2223; (d) Hayaishi O 1966 Bacteriol. Rev. 30 720

8. (a) Ohlendorf D H, Lipscomb J D and Weber P C 1988 Nature (London) 336 403; (b) Ohlendorf D H, Orville A M and Lipscomb J D $1994 \mathrm{~J}$. Mol. Biol. 244 586; (c) Vetting M W, Earhart C A and Ohlendorf D H 1994 J. Mol. Biol. 236372

9. Vetting M W and Ohlendorf D H J 2000 Structure 8 429

10. Funabiki T, Mizoguchi A, Sugimoto T and Yoshida S 1983 Chem. Lett. 917

11. Funabiki T, Mizoguchi A, Sugimoto T, Tada S, Tsuji M, Sakamoto H and Yoshido S $1986 \mathrm{~J}$. Am. Chem. Soc. 1082921 
12. (a) Funabiki $\mathrm{T}$, Ishikawa $\mathbf{M}$, Nagai $\mathrm{Y}$, Yorita $\mathbf{J}$ and Yoshida S 1994 J. Chem. Soc., Chem. Commun. 1951; (b) Funabiki T, Yoneda I, Ishikawa M, Ujiie M, Nagai Y and Yoshida S 1994 J. Chem. Soc., Chem. Commun. 1453; (c) Funabiki T, Sakamoto H, Yoshida S and Tarama K 1979 J. Chem. Soc. Chem. Commun. 754; (d) Funabiki T, Tada S, Yoshioka T, Takano M and Yoshida S 1986 J. Chem. Soc., Chem. Commun. 1699; (e) Funabiki T, Konishi T, Kobayashi S, Mizoguchi A, Takano M and Yoshida S 1987 Chem. Lett. 719

13. Cox D D, Benkovic S J, Bloom L M, Bradley F C, Nelson M J, Que Jr L and Wallick D E 1988 J. Am. Chem. Soc. 1102026

14. Cox D D and Que Jr L 1988 J. Am. Chem. Soc. 1108085

15. Que Jr L, Kolanczyk R C and White L S 1987 J. Am. Chem. Soc. 1095373

16. Nishida Y, Shimo H and Kida S 1984 J. Chem. Soc., Chem. Commun. 1611

17. (a) Viswanathan R and Palaniandavar M $1995 \mathrm{~J}$. Chem. Soc., Dalton Trans. 1259; (b) Palaniandavar M and Viswanathan R 1996 Proc. Indian Acad. Sci., Chem. Sci. 108 235; (c) Viswanathan R, Palaniandavar M, Balasubramanian T and Muthiah T P $1996 J$. Chem. Soc., Dalton Trans. 2519; (d) Viswanathan R, Palaniandavar M, Balasubramanian T and Muthiah T P 1998 Inorg. Chem. 372943

18. Velusamy M, Mayilmurugan R and Palaniandavar M 2004 Inorg. Chem. 436284

19. Velusamy M, Palaniandavar M, Srinivasa Gopalan R and Kulkarni G U 2003 Inorg. Chem. 428283

20. Wong Y-L, Yan Y, Chan E S H, Yang Q, Mak T C W and Ng D K P 1998 J. Chem. Soc., Dalton Trans. 3057

21. Mialane P, Anzolabehere-Mallart E, Blondin G, Nivorojkine A, Guilhem J, Tcheratanova L, Cesario M, Ravi N, Bominaar E, Girerd J J and Munck E 1997 Inorg. Chim. Acta 263367

22. McDevitt M R, Addison A W, Sinn E and Thomson L K 1980 Inorg. Chem. 193655

23. Lauffer R B, Heistand II R H and Que Jr L 1983 Inorg. Chem. 2250
24. Merkel M and Muller F K and Krebs B 2002 Inorg. Chim. Acta 337308

25. Jo D H and Que Jr L 2000 Angew. Chem. Int. Ed. Engl. 394284

26. Davies M I, Orville A M, Neese F, Zaleski J M, Lipscomb J D and Solomon E I $2002 \mathrm{~J}$. Am. Chem. Soc. 124602

27. (a) Casella L, Gullotti M, Pintar A, Messouri L, Rockenbauer A and Gyor M 1987 Inorg. Chem. 26 1031; (b) Wang S, Wang L, Wang X and Luo Q 1997 Inorg. Chim. Acta 254 71; (c) Krebs B, Schepers K, Bremer B, Henkel G, Althus E, Muller-Warmuth W, Griesar K and Haase W 1996 Inorg. Chem. 352360

28. (a) Cox D D and Que Jr L 1988 J. Am. Chem. Soc. 110 8085; (b) Salama S, Stong J D, Neilands J B and Spiro T G 1978 Biochemistry 17 3781; (c) Koch W and Kruger H-J 1997 Angew. Chem., Int. Ed. Engl. 36 1342; (d) Lim J H, Lee H-J, Lee K B and Jang H G 1997 Bull. Korean. Chem. Soc. 181166

29. Pyrz J W, Roe A L, Stern L and Que Jr L 1985 J. Am. Chem. Soc. 107614

30. Yamahara R, Ogo S, Watanabe Y, Funabiki T, Jitsukawa K, Masuda H and Einaga H 2000 Inorg. Chim. Acta 300-302 587

31. (a) Lipscomb J D and Orville A M 1992 Met. Ions Biol. Syst. 28 243; (b) Que Jr L and Ho R Y N 1996 Chem. Rev. 96 2607; (c) Que Jr L 1999 in Bioinorganic catalysis (eds) J Reedijk and E Bouwman (New York: Marcel Dekker) 2nd edn, p. 269

32. (a) Mialane P, Tehertanov L, Banse F, Sainton J and Girerd J 2000 Inorg. Chem. 39 2440; (b) Mialane P, Anxolabéhère-Mallart E, Blondin G, Nivorojkine A, Guilhem J, Tchertanova L, Cesario M, Ravi N, Bominaar E, Girerd J-J and Münck E 1997 Inorg. Chim. Acta 263367

33. Jang H G, Cox D D and Que Jr L $1991 \mathrm{~J}$. Am. Chem. Soc. 113, 9200

34. Que Jr L, Lipscomb J D, Munck E and Wood J M 1977 Biochim. Biophys. Acta 48560

35. Pascaly M, Duda M, Schweppe F, Zurlinden F, Muller K and Krebs B 2001 J. Chem. Soc., Dalton Trans. p. 828 